\title{
Institutional Foundations of Legislative Speech
}

\author{
Sven-Oliver Proksch University of Mannheim \\ Jonathan B. Slapin University of Houston
}

\begin{abstract}
Participation in legislative debates is among the most visible activities of members of parliament (MPs), yet debates remain an understudied form of legislative behavior. This study introduces a comparative theory of legislative speech with two major implications. First, party rules for debates are endogenous to strategic considerations and will favor either party leadership control or backbencher MP exposure. Second, in some systems, backbenchers will receive less time on the floor as their ideological distance to the party leadership increases. This leads to speeches that do not reflect true party cohesion. Where party reputation matters less for reelection, leaders allow dissidents to express their views on the floor. We demonstrate the implications of our model for different political systems and present evidence using speech data from Germany and the United Kingdom.
\end{abstract}

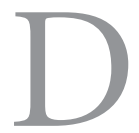

emocracy thrives through debate. Democratic parliaments provide an open forum for their members to publicly express their views, and members of parliament (MPs) dedicate a significant amount of their time to preparing speeches and participating in legislative debates. Yet, political scientists know surprisingly little about the role of political parties in debate, the institutions that govern access to the floor, and the strategic nature of the messages legislators try to convey. We put forward a comparative institutional theory of legislative debate in which we view speeches as the result of strategic choices made by party leaders and backbenchers. As a consequence of this strategic interaction, observed floor speeches may not reflect the true distribution of preferences within a party group. Party leaders must decide whether and to whom to delegate floor time. They have an incentive to present voters with a coherent party message, but some MPs may prefer to give a speech at odds with their party leadership, especially if doing so might help their own reelection bid. These strategic cal- culations can lead to substantial selection effects in the choice of speaker and the content of the speech.

This study proceeds by introducing our comparative theory of legislative debate and by discussing the empirical implications of our model for a variety of political systems. In scenarios where party unity matters for running successful election campaigns, party leaders should be reluctant to delegate speaking time to ideologically extreme members. Instead, as a party becomes ideologically more polarized, party leaders are likely to give more speeches representing the party line and delegate less often to members. In political systems where party unity matters less, but developing a personal reputation in parliament is essential for reelection, parties develop rules that make it easier for members of parliament with dissident views to take the floor. As a result, partisan rules governing legislative debate are endogenous to electoral considerations.

We test the most important implications of the model using newly collected legislative speech data from two

Sven-Oliver Proksch is a Research Fellow at the Mannheim Center for European Social Research (MZES) and the Research Center SFB 884 "Political Economy of Reforms," University of Mannheim, 68131 Mannheim, Germany (proksch@uni-mannheim.de). Jonathan B. Slapin is Assistant Professor of Political Science, University of Houston, Philip Guthrie Hoffman Hall, Room 447, Houston, TX 77204-3011 (jslapin@uh.edu).

The authors are listed alphabetically. Both authors have contributed equally to all work. We thank Kira Killermann, Linh Nguyen, and Sander Ensink for excellent research assistance and Serra Boranbay, Thomas Bräuninger, Thomas Gschwend, Christopher Kam, Thomas König, Elisabeth Schulte, Georg Vanberg, Jonathan Woon, and seminar participants at the University of Mannheim, Rice University, EITM Europe, and the DVPW Working Group on Behavioral Decision Making for helpful comments and suggestions. We especially thank Thomas Gschwend, Hermann Schmitt, Andreas Wüst, and Thomas Zittel for sharing the German candidate survey data. Sven-Oliver Proksch acknowledges that the research leading to these results has received funding from the European Community's Seventh Framework Programme (FP7/2007-2013) under grant agreement number 239268 (Marie Curie International Reintegration Grant).

American Journal of Political Science, Vol. 56, No. 3, July 2012, Pp. 520-537

(C)2012, Midwest Political Science Association

DOI: 10.1111/j.1540-5907.2011.00565.x 
parliaments, the UK House of Commons and the German Bundestag. ${ }^{1}$ We show that political institutions in these countries create different incentives for legislative speech-making. Party rules governing debate in the House of Commons do not give leaders formal powers to prevent backbenchers from taking the floor, nor have parties developed them. In Germany, parties have developed rules to provide the party leadership with control over the agenda. Confirming our model's predictions, the data provide evidence that German party leaders give more speeches relative to backbenchers to preserve party unity, whereas UK leaders do not. Using MP-level data, we furthermore find that, ceteris paribus, German MPs who are ideologically distant from their party leadership tend to give fewer speeches. In contrast, British MPs who are ideologically distant from their party leadership speak more often.

Our results have implications for the comparative analysis of party systems, intraparty politics, legislative institutions, and for the analysis of political text as data. For scholars interested in party politics, our model explains how strategic considerations put pressure on party leaders to control the party message in the legislature, despite the conventional notion that legislatures are open, deliberative forums. For scholars interested in legislative institutions, we show that legislative debates are governed primarily by partisan rules that are endogenous to the electoral context. And, finally, for scholars interested in using political texts as data, our findings suggest that measurement models must account for the fact that observed legislative speeches may, in some instances, underestimate the variation of preferences within a party.

\section{Party Politics and Legislative Speech}

There are two potential reasons why legislatures devote time to debate. First, debate may affect policy outcomes as MPs try to persuade colleagues of the superiority of their position. Second, debates may function as a forum for communication in which MPs explain votes and policy positions to their parties, other parties, and voters. The existing formal literature focuses on legislative speech as a tool for persuasion and finds it largely ineffectual. ${ }^{2}$ For

\footnotetext{
${ }^{1}$ The replication data set is available at http://www.mzes. uni-mannheim.de/users/proksch/.

${ }^{2}$ But see Dewan and Myatt (forthcoming) for a formal model of speech as communication, albeit not in the institutionally constrained setting of a parliament. The primary difference between their model and the model presented here is that in their model, the leadership arises endogenously and aggregates the preferences of the party members, but only leaders communicate the party message. In our model, the leadership and party positions
}

example, assuming that legislators are asymmetrically informed about the consequences of legislation, AustenSmith (1990) presents a model in which speech, viewed as cheap talk, may influence decision making through information revelation. He finds, though, that the role of debate in this model is limited to timing. Members of parliament can only share the same information that would be revealed during voting at an earlier stage; this may improve legislation, but only in some instances (AustenSmith 1990, 144). However, Austen-Smith himself notes that such a model cannot address whether speeches serve other functions, such as communication of policy positions to voters or parties. Given that speech is very unlikely to have any direct impact on legislation, if the persuasive impact of speech were all that legislators cared about during debate, we would not expect to find any systematic variation in the organization of legislative debate. Indeed, we would expect not to find much legislative debate at all.

However, once party competition is considered, new explanations for legislative speech arise. According to this view, MPs keep electoral considerations in mind when delivering speeches in parliament. A growing literature has suggested that politicians use parliamentary speeches to attract media attention and to sell an individual position to the public (Maltzman and Sigelman 1996), that politicians put more emphasis on symbolic and social issues in speeches when elections approach (Quinn et al. 2010), and that governing parties use legislative speeches to differentiate their position from that of a coalition partner come election time (Martin and Vanberg 2008). In his empirically rich study on parliamentary discipline in Westminster systems, Kam (2009) furthermore demonstrates that MPs use parliamentary dissent, broadly conceived, to secure personal support at the polls. He shows that dissent provides MPs with name recognition and popular approval that translate into votes. The magnitude of the effect of dissent on electoral success is approximately the same as the effect of constituency service (Kam 2009, 128). The party, however, suffers from dissent. Kam shows that a British voter's probability of voting for a party perceived as divided is $13 \%$ lower than for a party perceived as united $(2009,140)$.

Following this literature, we do not view speech as having a persuasive effect in the legislative process. Rather, we examine legislative speech as a tool for position taking for MPs and their parties. Several empirical phenomena suggest that political parties use legislative speeches to send policy signals as part of party competition. From a comparative perspective, parties in parliament differ in the attention they devote to structuring legislative

are exogenous, but backbenchers play a key role in communicating party positions. 
debates. Some parties write detailed rules to clarify which of their MPs receive priority in legislative debates, while others do not. This variation cannot be explained by a model of private information transmission or persuasion. Moreover, legislators spend substantial amounts of their time on debates. British MPs report that attending House of Commons debates is one of their most important activities in terms of hours spent per week after constituency service. ${ }^{3}$ Given that legislators could spend their time on other activities, what is the benefit of investing time in debate? One potential benefit is the ability to present a party or personal message to voters, as legislative debate receives coverage in all types of media. In Germany, a leading newspaper, the FAZ, has published, on average, 73 stories per year mentioning debates in the German parliament since 1950, amounting to more than one story about each plenary session. ${ }^{4}$ In addition, legislative speeches lend themselves to television broadcasts, and news stations show excerpts of legislative debates on a regular basis. Many parliaments offer live feeds of legislative debates on their websites and make videos accessible to everyone. Combined, this suggests that legislative speeches contribute to the electorate's perception of legislators and parties.

As legislators are likely aware of these consequences, we argue legislative debate is best explained by a strategic model of position taking. Intraparty politics and electoral considerations are key to understanding how legislative debate is structured. Parties are collective actors and internal disagreements may affect, among other things, how successful a party is on election day (Kam 2009). At the core of our theory is the notion that party names can serve as brands that signal the core party platform to voters (Aldrich 1995; Cox and McCubbins 1993). To maintain the party's brand, party leaders must monitor their elected members and prevent them from undertaking activities that contradict the party's primary message. Although the party benefits from unity, individual MPs may be hurt by toeing the line. For instance, an MP may have been elected in a district ideologically at odds with the official party stance. This creates a collective action problem: while the party as a whole might be better off when members communicate party policy, individual members are better off by presenting their own position while reaping the benefits from other members who toe the party line. The severity of this collective action problem is a function of political institutions, and solutions come in the form

\footnotetext{
${ }^{3}$ Data are average responses from the British Representation Study $1992,1997,2001$, and 2005 to the question of how many hours are devoted to particular activities in the average week when the house is sitting. Further information is given in the online supplementary appendix.

${ }^{4}$ Further information is given in the supplementary appendix.
}

of party leadership and partisan institutions (Cox and McCubbins 1993; Kam 2009).

It is well known that institutions-such as electoral systems, regime type, and candidate selection mechanisms - affect legislative behavior, and therefore, party unity (e.g., Bowler 2000; Carey 2007; Carey and Shugart 1995; Crisp et al. 2004; Diermeier and Feddersen 1998; Gallagher and Marsh 1988; Hix 2004; Huber 1996). Most studies have focused primarily on how these institutions affect party cohesion evident in roll-call voting (e.g., Carey 2007, 2009; Hix, Noury, and Roland 2007; Kam 2009; Londregan 2002). Recently, however, scholars have pointed out biases in the sample of recorded votes and their potential distorting inferences about party cohesion (Carrubba, Gabel, and Hug 2008; Carrubba et al. 2006; Hug 2009; Roberts 2007 ). Problems of selection bias in roll-call votes have led researchers to explore legislative speeches as an alternative indicator of party cohesion. Speeches have been used to estimate ideology of members of parliaments (Diermeier et al. 2012; Laver and Benoit 2002; Monroe and Maeda 2004), governments (Giannetti and Laver 2005), and parties (Proksch and Slapin 2010). Others have used legislative speeches to assess congressional support for bills (Thomas, Pang, and Lee 2006), the dimensionality and the nature of rhetorical conflict in Congress (Monroe, Colaresi, and Quinn 2008; Quinn et al. 2010; Schonhardt-Bailey 2008), and the nature of ideology surrounding specific policies such as national security (Schonhardt-Bailey 2005). However, if legislative speech is subject to selection effects, these data may not accurately reflect the true distribution of preferences.

There is one fundamental difference between legislative speech and legislative voting: while all MPs may cast a vote, generally speaking not all members may give a floor speech. To date, models of comparative legislative behavior have not incorporated this fact. Plenary time is scarce. Cox (2006) has referred to this scarcity as a "plenary bottleneck," arguing that institutional arrangements that provide some MPs with agenda-setting rights are necessary to prevent total legislative gridlock. In a legislative "state of nature" without any limits on debate, nothing would get accomplished. The agenda bottleneck comprises two elements. The first is access to the voting agenda - the right of actors to make proposals to the legislature. The second is access to the debate agenda - the right of members to express opinions in speeches. ${ }^{5}$ The voting agenda has been the primary focus of the literature on legislative organization (e.g., Cox and McCubbins 1993, 2003; Döring 1995; Shepsle and

\footnotetext{
${ }^{5}$ Indeed, without rules for controlling speaking time, as in the precloture U.S. Senate, every MP could, in principle, block any bill simply by talking indefinitely. See Bawn and Koger (2008) for a formal model explaining the use of the filibuster during this period.
} 
Weingast 1987; Tsebelis 2002). The second element of the bottleneck, however, remains surprisingly unexplored. Yet, it is precisely this bottleneck that leads to selection effects, as there is not enough time for all members to speak. How parties navigate this bottleneck determines the type of selection effects. We expect that parties approach the scarcity problem differently as a function of institutions and the incentives they create for party competition. By examining these institutional constraints and partisan reactions to them, our theory identifies the conditions under which observed floor speeches accurately reflect true intraparty cohesion.

\section{A Formal Model of Legislative Speech}

We argue that legislative speeches are part of a delegation game played between the party leadership and backbenchers. In many democracies, both parliamentary and party rules allow party leaders to control access to the floor. Even in systems where parliamentary rules mean party leaders cannot formally prevent backbenchers from giving a floor speech, party leaders can still design party rules to control who takes the floor. For example, party leaders could ask to pre-approve backbencher speeches that potentially clash with the party line and punish backbenchers who speak without first seeking approval. Likewise, party whips could monitor the content of backbencher speech and seek to punish those members who dissent. In short, party rules controlling access to floor time are endogenous; parties design them to give MPs, and therefore the party, the best chance at reelection.

While party leaders are expected to be active in communicating party policy, they have an incentive to delegate floor time to members. Backbenchers are likely to have specialized knowledge about a bill and may, therefore, be in a better position to advertise the bill than the party leader. In addition, the leader may wish to provide MPs with the opportunity to build a reputation on the floor and within the party. Where the electoral system requires the MP to cultivate a personal vote for reelection, this may be particularly important. However, delegation involves costs. While the party leader knows exactly what he would say if he were to give a speech, he does not exercise such precise control over his backbenchers. An MP could publicly deviate from the party line. Dissent in speeches may serve as a pressure release valve for party members at odds with the party position, but there are costs. If a sufficient number of MPs give such speeches, they could dilute the value of the party label. The leader can limit these costs by making it more difficult for the MP to take the floor.
In our model, the parliamentary party is composed of $n$ members, whose ideological positions lie in a onedimensional policy space. Each party member $i$ has an ideal point $x_{i} \in \mathfrak{R}^{+}$. The party leader $L$ also has an ideal point $x_{L}$ (set to 0 without loss of generality), which is assumed to represent the official party policy. The game starts when the party delegation is allocated speaking time according to the parliamentary rules of procedure. First, a potential speaker from within the party delegation is chosen. The recognition rule is neutral, and a member is selected at random- $M$ is drawn with equal probability $p_{M}$ from the set of (nonleader) party members. After having observed $M$ 's identity, the party leader $L$ chooses either to deliver a speech on behalf of the party or to delegate this task to the member $M$. If $L$ chooses to deliver a speech $x_{S}$, he will advocate the official party policy on the floor of parliament, his own position $x_{S}=x_{L}$. If $L$ decides to delegate the task of speechmaking, party member $M$ delivers a speech that contains a policy message located between $M$ 's and L's ideal points, $x_{S} \in\left[x_{M}, x_{L}\right]$. In other words, a party member will propagate any policy between his and the party leader's ideal point.

\section{Utility Functions of Party Leaders and MPs}

To the extent that members' preferences deviate from those of their leadership, MPs face a trade-off between advocating their preferred policy alternatives and securing access to political office. For some, the promotion of their favored policy alternative is clearly more important than toeing the party line. For others, advancement in parliament or the party is a more desirable goal, in which case they will put greater weight on the party message in their speeches. We capture the trade-off between policy and office through an MP-specific weight parameter. The party member's utility function is

$$
U_{M}=-\lambda_{M}\left(x_{S}^{i}-x_{M}\right)^{2}-\left(1-\lambda_{M}\right)\left(x_{S}^{i}-x_{L}\right)^{2},
$$

where $x_{S}^{i}$ is the position of the speech delivered by $i=\{L, M\}, \lambda_{M} \in(0,1]$ is the weight the member places on deviations from his own policy position in legislative speeches, and $1-\lambda_{M}$ is the weight placed on deviations from the leader's position. When the leader delegates, the speech $x_{S}$ is delivered by the member, who cares both about the degree to which a speech he delivers deviates from his own position, as well as the degree to which the speech deviates from the party leader's position. A member may value party unity to the extent that it helps him in his reelection bid. The party leadership is likely to reward members who display behavior that fosters party unity. To receive benefits from the party, such as leadership 
positions within the parliament or the party, party support for a reelection bid, or a safe position on the party list in a closed-list electoral system, the member must show support for the party's official position. Party support for a member is likely to increase as a member's floor speeches display greater support for the party leadership's position. Finally, when the leader does not delegate, the position of the speech $x_{S}$ will equal the leader's position $x_{L}=0$. In this case, the member suffers a utility loss $-\lambda_{M} x_{M}^{2}$ as he is unable to advocate his position at all.

Leaders trade off the goal of party unity with the goal of public visibility. Intraparty disagreement can damage the party by weakening the leadership, pitting one party faction against another, and causing confusion about the party message in the media and the electorate, all of which can cost the party votes at election time. However, the party leadership also has an incentive to allow party members to take the floor as policy experts because it helps the party build and maintain a public profile independent of the actual party platform. ${ }^{6}$ The goals of party unity and public exposure are difficult to achieve simultaneously. If leaders deliver speeches themselves, they ensure party unity, but they reduce the public exposure of their backbencher MPs and thus the party profile. If leaders delegate all speechmaking to their MPs, they raise the profile of the party's MPs but put party unity at risk. We represent the leader's trade-off between party unity and party profile as a leader-specific weight parameter. The party leader's utility function is

$$
\begin{aligned}
U_{L}= & -\pi_{L}\left(x_{S}^{i}-x_{L}\right)^{2}-c_{L} \\
& +I_{L=D}\left(c_{L}+\left(1-\pi_{L}\right) e_{L}\right),
\end{aligned}
$$

where $x_{S}^{i}$ is the position of the speech delivered by $i=\{L, M\}, \pi_{L} \in(0,1]$ is the weight the party leader places on party unity, $1-\pi_{L}$ is the weight the leader places on the public exposure of the party, $e_{L}>0$ is the public profile benefit received by the leader if the leader delegates to a member $\left(I_{L=D}=1\right)$, and $c_{L}>0$ is the cost that the leader pays if he decides to deliver the speech himself. If the leader gives a speech, $x_{S}=x_{L}=0$, there is no loss to party unity. However, there is a loss if the leader delegates and the member propagates a position other than $x_{L}$. All else equal, the leader prefers to delegate the task of speechmaking to the member. The public exposure benefit $e_{L}$ is positive. Members gain experience on the floor of parliament, honing their skills for future

\footnotetext{
${ }^{6}$ Alternatively, party leaders may wish members to express some diversity of views to appeal to a wider set of voters, but only up to a certain point. Beyond this threshold, when too much diversity is expressed, the party's policy position may lose focus, and the party may no longer send a clear signal. This interpretation is also in line with our model.
}

party leadership roles. The cost to the leadership of giving a speech $c_{L}$ is also positive. Preparing a speech requires time and effort that could be better spent on other activities. Leaders are unlikely to be experts on all topics, so speech preparation means acquiring the necessary information, something which specialist MPs are likely to possess already.

\section{Equilibria}

The game is sequential. First, a member, chosen at random, is recognized as a potential speaker. ${ }^{7}$ The party leader then learns the policy preference of the selected MP, $x_{M}$, as well as the weight, $\lambda_{M}$, he places on expressing his policy position. The leader decides whether to delegate the task of speechmaking, and, if delegated to, the member selects the position of his speech and gives the speech on the floor. We examine the conditions under which the leader will delegate the task of speechmaking to the member. The equilibrium concept is subgame perfection.

Proposition. If the party leader delegates, the member gives a speech $x_{S}^{*}=\lambda_{M} x_{M}$. Delegation occurs if and only if

$$
x_{M} \leq \sqrt{\frac{e_{L}\left(1-\pi_{L}\right)+c_{L}}{\lambda_{M}^{2} \pi_{L}}} .
$$

The proof is in the appendix. If delegated, the member selects $x_{S}$ to maximize his utility. A member who solely values his own position $\left(\lambda_{M}=1\right)$ will give a speech at his own ideal point. A member who highly values the position of the party $\left(\lambda_{M}\right.$ close to 0$)$ will give a speech very close to 0 , the leader's ideal point $x_{L}$. A member who values his own and the party's position will give a moderate speech. The leader, knowing the location of the speech that the member will give if delegated time, must decide whether to delegate time or not. He does so only when the condition in inequality (3) holds. When the ideological distance between the member and the leader crosses the threshold, the leader does not delegate in order to prevent the member from delivering a speech that differs substantially from the official party policy. In this case, the leader's utility is simply $-c_{L}$, and the member's is $-\lambda_{M} x_{M}$.

These equilibria inform us about the type of party member to whom a party leader is likely to delegate floor time and the position of the speech the member is likely

\footnotetext{
${ }^{7}$ In reality, some MPs are more likely to be experts on issues than others. For simplicity, we assume that expertise within policy areas is distributed across the entire ideological spectrum of the party, but we later control for it in the empirical analysis.
} 
to give. When a member holds an ideological position sufficiently distant from the position of the party leadership, the leader will not delegate floor time and will instead give the speech himself. This result, though, is mitigated by the weight that party leaders and members place on party unity. In political systems where party unity is valued less, the party leader will delegate to a more ideologically diverse set of members.

\section{Empirical Implications}

The model has empirical implications for the status of the speaker (backbencher or leader), the position expressed in speeches, and the degree to which backbenchers make concessions to the official party position in their speeches. The parameters of the model vary according to the electoral incentives created by the political systems. In addition, the parameters may vary within a single country's parliament due to different incentives faced by different members. By setting parameter values in our model to match features of different political systems, we study a variety of theoretical scenarios.

Scenario 1: Presidential system with majoritarian electoral system. The electoral independence between legislature and executive means that party leaders do not place much weight on party unity. Parties need not be cohesive to secure the confidence of the government, and party labels are less important because each MP runs his or her own reelection campaign. In the U.S. Congress, therefore, we would not expect party leaders to interfere with the speeches of legislators. Studies have found that ideologically extreme members make more use of unconstrained floor time and have confirmed that members of the minority party speak more often (Maltzman and Sigelman 1996; Morris 2001). Yet, some research suggests that party leadership is nevertheless able to orchestrate unified speech campaigns in the House, although members more ideologically distant from the party leadership are less willing to give speeches supporting the party position (Harris 2005). In short, though party leaders may be able to exert some control over the party message in floor speeches, they do not prevent dissidents from taking the floor. The extant empirical evidence on the U.S. Congress thus supports our argument. ${ }^{8}$

Scenario 2: Parliamentary system with majoritarian electoral system. Due to the need to support a government,

\footnotetext{
${ }^{8}$ Even in the U.S. Senate, where all senators are entitled to speak if they so choose, there is evidence that minority party members speak more compared with members of the majority party, who are likely more constrained by their leadership (Quinn et al. 2010, 224).
}

parties in parliamentary systems will generally place more value on unity than parties in a presidential system. Nevertheless, the electoral system will also affect a party's desire to put forward a unified message. In parliamentary systems with electoral politics that emphasize individual candidates - the majoritarian, first-past-the-post electoral system, for example-parties are likely to value public exposure of backbenchers more, and place less weight on maintaining party unity. Members will also need to place more emphasis on their own positions and less on the position of the party. While the party can help get a member elected, the member must pander to his district rather than the party. The party has comparatively less to offer members in these candidate-centered systems. While the party leadership may retain more control than they would in Scenario 1, we still expect that leaders delegate speaking time to their membership to allow them to make a name for themselves and to express the preferences of their district.

Scenario 3: Parliamentary system with closed-list proportional representation. Parties in a parliamentary regime that uses a closed-list PR electoral system will place high value on party unity, as voters rely heavily on party "labels" to make up their mind come election time. Public exposure of backbenchers will not bring parties many benefits, as politics is less about personalities of individual parliamentarians than parties in these systems. In terms of our model, party leaders are likely to have a $\pi$ that approaches 1 and an $e$ very close to 0 . Likewise, members of parliament are likely to place greater weight on the party position than on their own position ( $\lambda$ will be small). The party controls access to most things that members value. Without the support of the party, reelection is impossible. It is also nearly impossible to make a name for oneself in politics without climbing the party ranks. All this entails placing the party position over one's own position. The leadership will be very selective in whom they allow onto the floor.

Scenario 4: Parliamentary system with mixed-member proportional representation. In addition to looking at two most dissimilar parliamentary systems, we also look more closely at the incentives created by one particular system which combines aspects of Scenarios 2 and 3, the mixedmember proportional (MMP) electoral system. Mixedmember proportional representation systems, such as Germany or New Zealand, combine elements of closedlist PR with single-member districts (SMD). Parties draw up candidate lists that cannot be altered by voters, but parties also run candidates in single-member districts. Voters vote twice. First, they cast a ballot for a closed party list and then they vote for a candidate in their single-member electoral district. While the winners of 
the SMDs are guaranteed a seat in the new parliament, the SMD votes do not determine a party's overall seat share. Instead, parties' seat shares are proportional to the number of list votes they receive. This means that party leaders' incentives are very similar to those in a pure closed-list system. They wish to maximize the number of ballots cast for their party list. This requires placing a great deal of weight on party unity. Backbenchers, though, face different incentives depending upon whether they are elected off the list or from an SMD. Members elected off the list face incentives very similar to backbenchers in any other closed-list PR system, and they are likely to weigh the party's position quite highly (Scenario 4a). Their reelection chances increase when the party wins a higher percentage of list votes. Members elected out of a single-member district, on the other hand, have a guaranteed seat regardless of how many votes are cast for their party's list. They simply need to retain support in their district. These members are likely to place higher weight on their own ideal point over the ideal point of the party (Scenario 4b). ${ }^{9}$ Thus, by looking at these two types of candidates for election in MMP systems, we can generate predictions by altering only one of the parameters of the model, $\lambda$. Members elected from SMDs should place greater value on their own policy position (have a higher $\lambda$ ) than those members elected off the list.

Figure 1 plots the simulated positions expressed in legislative speeches and the type of speaker (MP or party leader) as a function of the selected member's distance from the party leadership for the political systems described above. In all systems, as the member's position deviates from the leader's position, the MP's speech also deviates from the speech the leader would give. However, the MP's position expressed in the speech also deviates from his own position (because $\lambda<1$ ). If a member were to completely disregard his own position and only give speeches at the leader's position, the speech position line would be horizontal at 0 . On the other hand, if a member were to completely disregard the party position, the position expressed in the speech would correspond to the MP's ideology (depicted in the figure by the thin 45-degree line). For a given ideological distance between the MP and the leader (shown on the horizontal axis), the deviation of this speech from the 45-degree line represents the member's concession to the leadership. This speech line is shown in thick black. Once a specific ideological threshold is crossed, the leader stops delegating

\footnotetext{
${ }^{9}$ Of course, even candidates elected out of SMDs care about the overall number of seats their party wins. They wish to see their party have more influence over policy and would like their party to join the government. However, their own personal fate is less tied to the party's overall electoral outcome.
}

to the member and gives the speech himself. The scenarios differ, first, in how much the MP moderates her speech and, second, in the point at which the party leader intervenes.

In the first scenario (presidential system with a majoritarian electoral system), the party leadership has few incentives to intervene because there is little weight placed on party unity. A member's speech will correspond closely to her true ideology, ${ }^{10}$ meaning she barely needs to moderate the content of her speech to get the leader to delegate to her. In Scenario 2 (parliamentary system with majoritarian electoral system), the MP places a slightly reduced weight on her own position compared with Scenario 1, and the party leadership now places more weight on party unity. This yields a more moderate backbencher speech (the slope of the diagonal line is flatter) and a threshold value that leads the leadership to cease delegation earlier relative to Scenario 1. In Scenarios 3 and $4 a$, representing closed-list PR (and those MPs elected off the list in MMP systems), the leader allows the member to express an even smaller range of positions on the floor, and the member moderates her speech even more compared to Scenario 2. Leaders are less likely to delegate to potential dissidents. Finally, Scenario $4 \mathrm{~b}$ represents those MPs elected in single-member districts in mixed-member proportional systems. Comparing this scenario with those MPs elected off the list (Scenario 4a), party leaders are more willing to delegate speeches to party-list MPs. Members elected out of SMDs are less willing to moderate their speeches as their ideology deviates from that of the leadership. Independent of whether the MP was elected off the list or from an SMD, leaders are only willing to accept an MP's speech which deviates so far from the party line. When faced with two backbenchers, one elected from an SMD and the other elected off the list, with the exact same ideological distance to the leadership, there is a range of ideological positions where the leadership is willing to delegate to the list member but not to the SMD member. Consequently, single-member district MPs in an MMP system will display legislative speech patterns very different from single-member district MPs in a majoritarian system, but they will also differ from the list candidates in their own system. A nonstrategic perspective would predict that single-member district MPs should deliver more speeches than their list counterparts due to their stronger electoral connection, while our model predicts the opposite.

\footnotetext{
${ }^{10}$ Or at least the ideology of the constituents with whom she is attempting to communicate.
} 


\section{FIGURE 1 Legislative Speech Delegation: Simulation of Institutional Scenarios}
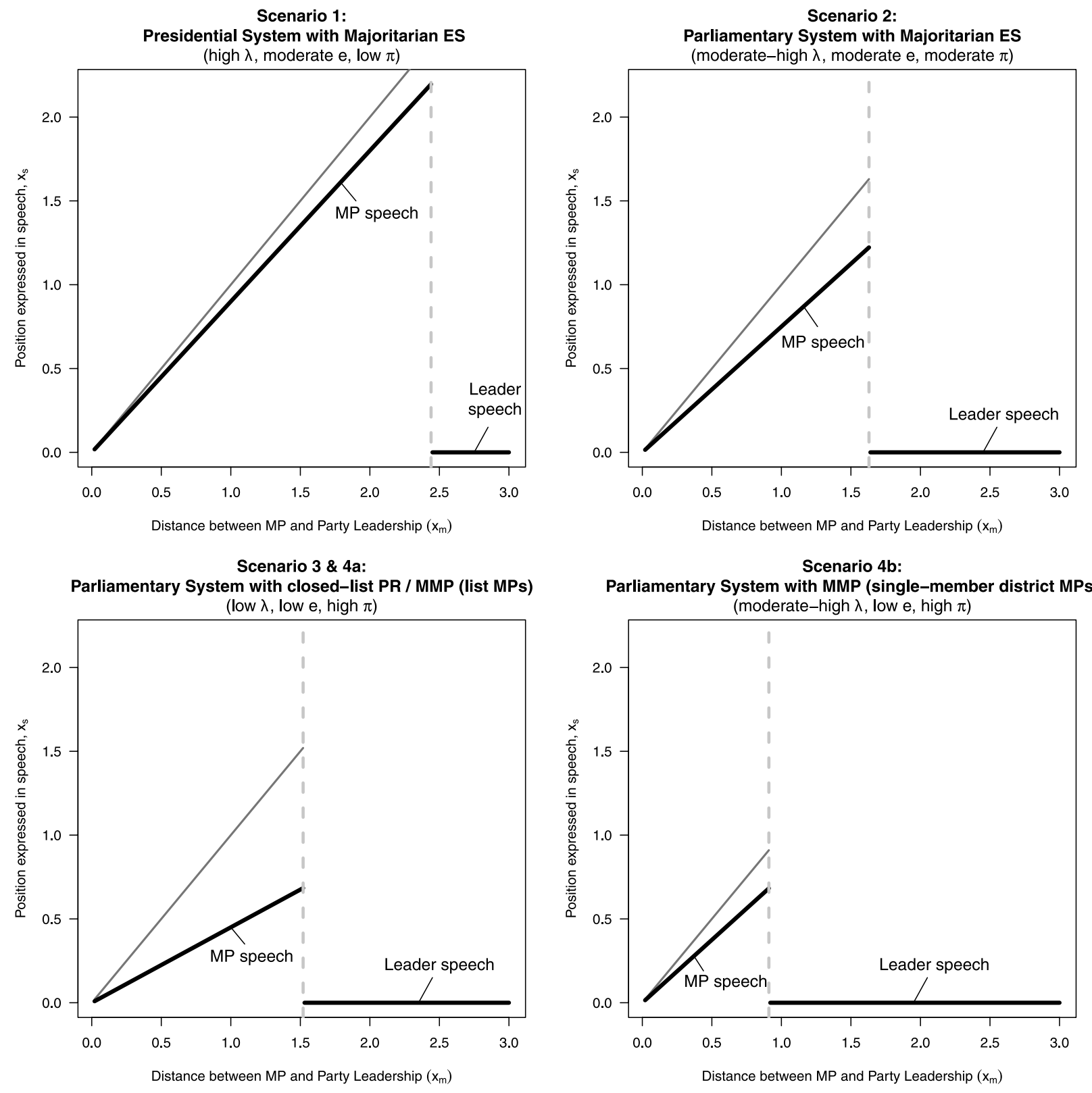

\section{Legislative Speeches in Germany and the UK}

We test the implications of our model on legislative speech data from Germany and the United Kingdom. These countries are chosen because they provide variation on several of the most important independent variables in our model. First, they allow us to match three of the four scenarios presented above. The United Kingdom provides an example of parliamentary democracy with a majoritarian electoral system (Scenario 2), while the German
MMP electoral system allows us to examine members in a closed-list system (Scenario 3/4a) as well as members who run in single-member districts within an MMP system (Scenario 4b). Second, because they are both parliamentary democracies, we control for regime type, meaning differences in the values that members and leaders place on the party label are most likely a function of the electoral system. Third, choosing countries representing Scenarios 2-4 also presents a harder test for our model than comparing Scenarios 1 and 3. We would expect to find the starkest differences between a presidential SMD 
system, such as the United States, and a closed-list PR system. If we find significant differences between the United Kingdom and Germany in how parties handle speakingtime allocation, our findings can only get stronger by looking at a country such as the United States.

We first discuss how the party rules for floor debates in the United Kingdom and Germany differ. UK parties have not developed formal rules to prevent backbenchers from taking the floor, whereas in Germany, party rules do provide the leadership with control over the speech agenda. Second, we introduce new data on legislative speeches in the United Kingdom and Germany. Partylevel data on number of speeches given by leaders and backbenchers provide evidence that German party leaders give more speeches relative to backbenchers, whereas UK leaders do not. Individual-level data from both countries confirm the model's expectations with regard to the ideological selection effect-in Germany, party members who are ideologically distant from their party leadership are less likely to speak; in the United Kingdom, ideologically distant MPs are more likely to take the floor than backbenchers who toe the party line. Lastly, the German data provide some evidence for differences between the types of MPs. Members elected in single-member districts tend to give fewer speeches than members elected from party lists, but this effect gets weaker as we control for the ideological distance between backbenchers and leaders.

\section{The Institutions}

Our theory suggests that where party labels matter more for reelection, party leaders will exercise more control over floor speeches. For party leaders to exercise control, parties must first develop the rules that would allow them to prevent dissident speech. In systems where party labels matter the most, we would expect parties to devise the strongest rules regarding the delegation of speaking time. Where party labels are comparatively less important for elections, parties are less likely to have written rules regarding the delegation of speaking time. In fact, they may benefit from the lack of rules-they cannot prevent a backbencher from making a dissident speech that could help the backbencher electorally.

The UK House of Commons rules of procedure make no mention of parties in the allocation of speaking time, but they do set out in detail the rules structuring parliamentary debate. Rather than parties controlling the House of Commons' speakers list, this task is delegated to a nonpartisan figure, the Speaker of the House. It is the Speaker's job to control the flow of debate. Backbenchers do not require the formal support of their party leadership to participate in debate. An MP who wishes to speak may submit his name to the Speaker in advance, but then must "catch the speaker's eye" during debate by rising from his seat. While the Speaker often gives frontbenchers precedence over backbenchers, the frontbenchers cannot prevent the Speaker from calling on any particular backbencher. In fact, the newest members are given the highest precedence. A new MP who has not yet made a speech is generally called before other MPs rising at the same time, and the member is allowed to make his maiden speech (McKay 2004, chap. 18).

In Germany, party leaders play a more significant role in the allocation of speaking time to MPs. Each parliamentary party receives speaking time according to a formula that accounts for both proportionality and parity between government and opposition parties (Schreiner 2005). The parties then decide on their own speaker lists. The relevant institutions governing the intraparty allocation of speaking time can be found in the rules of procedure for each party group (Fraktion). These rules provide the party leaders with procedural means to prevent dissident speakers from taking the floor, or at least monitor them when they do. Each party group gives spokespersons on a policy a privileged role in debate and usually stipulates that the official party line should be delivered in the speech. ${ }^{11}$

In short, the institutions in both systems reflect the incentives created by the political and electoral system. In Germany, parliamentary party leaders have the means to check party members, and the rules ensure that the party leadership remains central in deciding who may deliver the party message in parliament. In contrast, parties in the United Kingdom have not developed formal means to prevent dissidents from taking the floor. The institutions reflect the fact that creating a name for oneself on the floor of parliament is potentially important for an MP's reelection and the party's success. ${ }^{12}$

\section{The Speeches: Party-Level Analysis}

To test the empirical implications of the model, we first examine speech data at the party level for each legislative term of the German Bundestag between 1976 and 1998 and of the British House of Commons between 1997 and

\footnotetext{
${ }^{11}$ The procedures for each party are described in detail in the supplementary appendix.

${ }^{12}$ Another way to assess the effects of institutions would be to examine whether institutions regarding speaking-time allocation change following a change of electoral rules. New Zealand, for example, has maintained some of the debate traditions of a Westminster system, while increasing the power of party leadership to control access to the floor following its move to a mixed-member proportional electoral system.
} 
2005. ${ }^{13}$ For Germany, this period includes both SPD- and CDU-led governments. In the British case, the period covers the Labour governments led by Tony Blair. For each parliamentary term, we collected information about each speech given on the floor, including the identity of the speaker, the speaker's status within his or her party (backbencher or party leader), and, for Germany, whether the speaker was elected off the party list or out of a singlemember district.

Our model predicts that the speech participation rate of party leaders should be substantively different in the two systems. A direct comparison of the participation rates, however, is not feasible for one simple reason: the definition of party leaders differs across systems. ${ }^{14}$ In Germany, party leaders include party group chairs (Fraktionsvorsitzender), party whips (Parlamentarischer Geschäftsführer), party working-group chairs (Arbeitsgruppenvorsitzender), and party chairs (Parteivorsitzender). We exclude speeches given by MPs who were government members, including chancellor, ministers, and junior ministers. Leaders of the United Kingdom's governing Labour party include whips, parliamentary under secretaries, and ministers of state. For the opposition, we define leaders as the shadow cabinet members and party leaders. We exclude speeches given by members of the cabinet. Government and cabinet members are excluded from the analysis because we cannot disentangle whether an MP gave a speech in the role of party leader or government member. This is especially problematic in the United Kingdom, where, even after excluding cabinet members, most party leaders from the governing party hold government roles (e.g., Minister of State or Parliamentary Under Secretary). Thus, it is difficult to determine whether leaders of the UK governing party are speaking in a parliamentary party leadership role or as a member of government. Because of this confounding between government and parliamentary leadership positions in the United Kingdom, the opposition Conservatives offer the best test of our theory.

When the proportion of leaders within parliamentary parties varies, either due to the nature of the political

\footnotetext{
${ }^{13}$ We choose the longest possible time periods given the availability of speech data and data on members of parliament (party affiliation, monthly membership in parliament, backbencher versus party leader status in parliament, and district versus list MP status for Germany). The data were collected from the online archives of both parliaments and from Bundestag (1998), Butler and Butler (2005), and Gay (2009). The online archives are available at http://www.publications.parliament.uk and http://dip.bundestag.de/.

${ }^{14}$ We include MPs in our analysis who we could uniquely assign as party leaders and backbenchers throughout the respective legislative term. Thus, we exclude MPs who switched status midterm.
}

system or the size of parties, we cannot directly compare the proportion of speeches that leaders in different parties give. Instead, we need to establish a baseline expectation for the activity of party leaders. An institution-free expectation is that each MP has the same probability of receiving floor time; the proportion of leader speeches should be proportional to leaders' seat share inside the party. We expect party leaders in Germany to give significantly more speeches than the seat share would suggest, but not in the United Kingdom.

Figures $2 \mathrm{~A}$ and $2 \mathrm{~B}$ plot the proportion of speeches given by party leaders for the major parties in the UK House of Commons and for the major parties in the German Bundestag. We generate 95\% confidence intervals for the proportion of speeches through a nonparametric bootstrap. ${ }^{15}$ These confidence intervals allow us to test whether the proportion of speeches is significantly different from the baseline expectation that speeches correspond to the seat share of the leadership relative to backbenchers. This baseline expectation is indicated in the figures by dotted vertical lines.

Figure $2 \mathrm{~A}$ shows that we cannot reject the null hypothesis that Conservative party leaders simply give speeches according to what we would expect given their seat share, while governing Labour parties do give slightly more speeches than what is expected under the null. The confidence intervals of the speech proportion of leaders include the seat share in both legislative periods for the Conservatives, but not for Labour. On average, party leaders from the governing Labour party gave around $16 \%$ of the speeches for their party and accounted for around $8 \%$ of the seats for their party in the House of Commons. Leaders from the opposition Conservative party gave on average $9 \%$ of the speeches and accounted for $7 \%$ of the seats of their party. The evidence thus supports the notion that British party leaders allow more floor time for backbenchers. Labour party leaders do speak slightly more than we would expect on the basis of their seat share. However, as pointed out earlier, it is very difficult to know whether these leaders speak in their capacity as government members or as a party leader due to the difficulty in disentangling the parliamentary roles from the governmental ones.

The picture is drastically different for Germany. Figure $2 \mathrm{~B}$ shows that party leaders of the major parties

\footnotetext{
${ }^{15}$ To do so, we simulate 1,000 speech scenarios by sampling from the leader speech vector and the backbencher speech vector with replacement. For each of these samples, the number of leader and backbencher speeches are counted, and the proportion of leader speeches calculated. The confidence interval covers the 2.5 th and 97.5th percentile of the resulting distribution of leader speech proportions.
} 

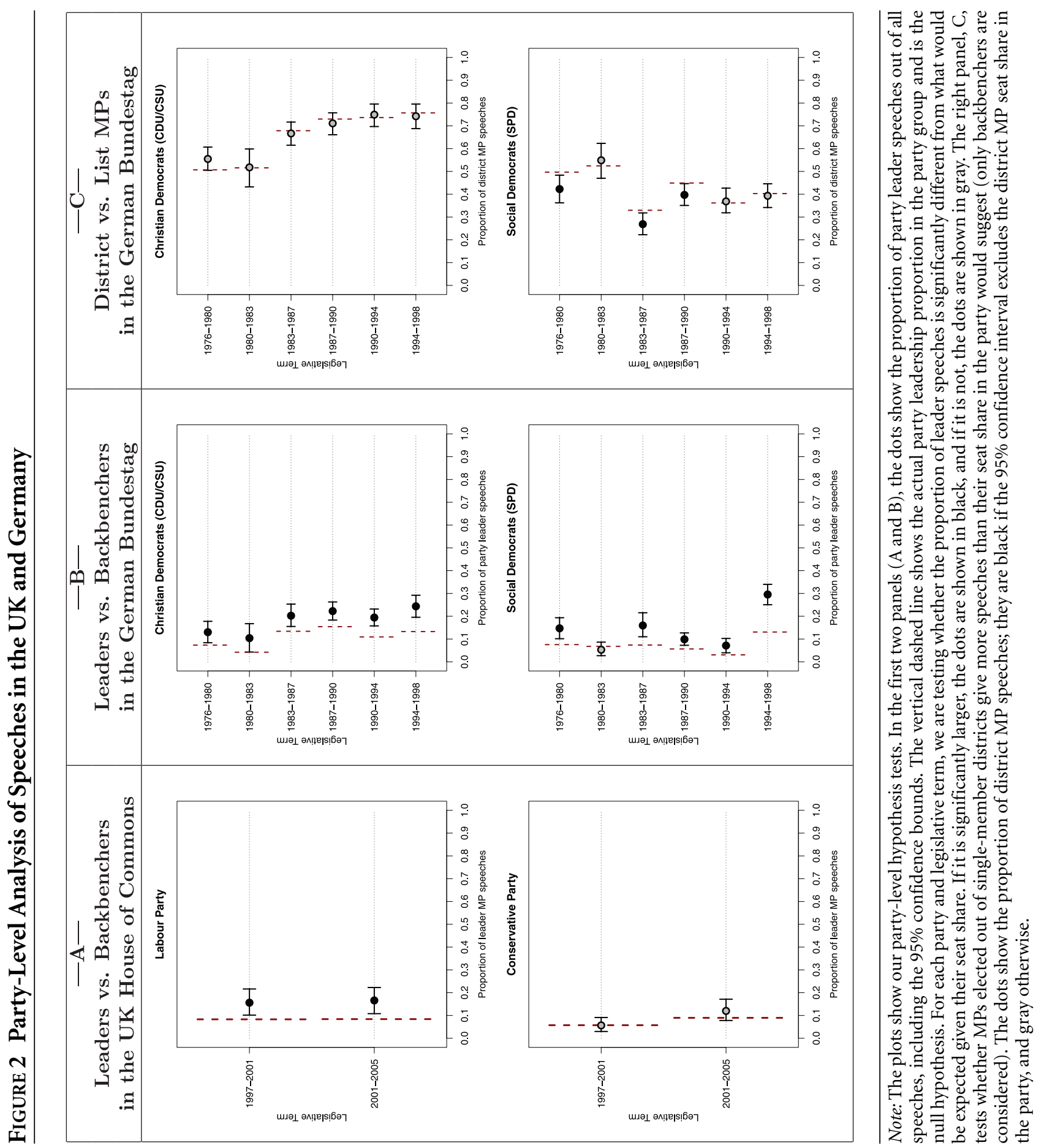
gave consistently more speeches than would be expected on the basis of their intraparty seat share. Across all legislative terms, the proportion of party leader speeches is around $80 \%$ higher for the Christian Democrats and $87 \%$ higher for the Social Democrats than the seat share of leaders in the party. The results are consistently significant; in all but one term the confidence intervals exclude the seat share. On average, CDU/CSU leaders account for $18 \%$ of the speeches, but only for about $11 \%$ of the seats, and SPD leaders account for $14 \%$ of the speeches, but only for $7 \%$ of the seats. ${ }^{16}$

In addition to examining the extent to which party leaders dominate legislative debates, the German system allows us to make a controlled comparison with regard to the weight MPs place on their position $\left(\lambda_{M}\right)$. Our institutional model suggests that, while MPs elected from SMDs would potentially prefer to give more speeches to bolster their personal image, party leaders have an incentive to keep them off the floor because they have a weaker incentive to support the party line than list MPs. Leaders must prioritize the goal of preserving the party label to maximize the list vote, as this determines overall seat share. Therefore, the leadership ought to favor floor time for the party-oriented list MPs over the SMD MPs. Figure 2C plots the proportion of speeches given by backbenchers elected out of single-member districts relative to their share of seats in the Bundestag for both major parties. The results either suggest that we cannot reject the null hypothesis that MPs elected out of SMDs give speeches according to their intraparty seat share or indicate that SMD MPs do in fact give fewer speeches than expected. In no legislative term is the proportion actually higher for SMD MPs. We interpret this as strong evidence for our model. ${ }^{17}$

\section{The Speeches: MP-Level Analysis}

While the party-level analysis is useful to compare the aggregate speech proportions of leaders and backbenchers, it does not allow us to test the model's implications with regard to ideology. Our model predicts that as a German backbencher's distance from the party leadership increases, the probability of delivering a speech decreases. In the United Kingdom, on the other hand, backbenchers with large ideological distances should be more likely to

\footnotetext{
${ }^{16}$ See the supplementary appendix for robustness checks regarding the coding of party leaders for the United Kingdom and Germany.

${ }^{17}$ We performed a robustness analysis checking that district MPs do not demand less floor time because they spend more time in their constituencies, which could be an alternative interpretation of the results. They do not (see supplementary appendix).
}

speak. We test these hypotheses by examining the number of legislative speeches given by each MP in both countries. Our dependent variables are the legislative speech counts during the 2005-09 legislative period in Germany, and the 2001-05 period in the United Kingdom. To generate ideological distances between MPs and the party leadership, we use MP self-placements on a left-right scale from the German Candidate Survey conducted in 2005 (Gschwend et al. 2005; Wüst et al. 2006; Zittel and Gschwend 2008) and the British Representation Study conducted in 2001 (Norris and Lovenduski 2001). These candidate surveys provide a measure of MP ideology that is exogenous to legislative behavior. Thus, we take this as our best guess for the latent ideological position of MPs.

The two candidate surveys differ with regard to the questions asked about the position of party leadership. The British Representation Study asks each MP to place his party's leadership on an 11-point left-right scale. To calculate the position of the party leadership, we take the average response of party members on this question. The German Candidate Survey does not include a question about party leadership. Instead, the survey asked members to place themselves, their party, and all other parties on an 11-point left-right scale. Because MPs rank every party, not just their own, we first apply a rescaling procedure to correct for the fact that every MP might perceive the scales differently (Aldrich and McKelvey 1977). ${ }^{18}$ After rescaling the self-placements, we calculate the leader position for each party as the median of the rescaled selfplacements of party leaders. Thus, we define the party leadership position as close to the theoretical idea as possible given the data available for both countries. We then calculate the absolute distance of each MP's left-right position from the party leadership position to arrive at our distance variable.

As control variables, we include party dummies and a party leader dummy in both models. The German models also include a dummy indicating whether an MP was elected from a party list (as opposed to in a district) and a variable counting the number of committees on which the MP served. The expectation is that MPs with more assignments are more likely to be experts on policy issues and therefore more likely to be considered for floor time. ${ }^{19}$ Finally, in the German case, we control for the fact that MPs from the governing coalition may respond to the constraint imposed by the coalition agreement between the

\footnotetext{
${ }^{18}$ We use the R package basicspace to estimate the location of MPs with the Aldrich/McKelvey algorithm (Poole et al. 2010).

${ }^{19}$ Because committees play a more significant role in the Bundestag, we consider this variable to be an important control for the recognition likelihood of each MP only in Germany.
} 
governing parties. To do so, we create a dummy variable indicating whether the MP is located outside the coalition interval defined by the party leadership positions of the $\mathrm{CDU} / \mathrm{CSU}$ and the SPD. If governing MPs do indeed respond to the coalition agreement, then they should be less likely to speak if they are outside the coalition interval, and the distance variable (which is calculated using the absolute distance from the leadership position) should not explain the variation in speech counts.

We run several negative binomial models predicting the number of speeches delivered by each MP as a function of ideological distance to the party and the control variables. ${ }^{20}$ Table $1 \mathrm{~A}$ presents the results for the United Kingdom and Table 1B for Germany. The United Kingdom and Germany differ with respect to the overall debate activity of their MPs. While British MPs gave on average 136 speeches in the 2001-05 legislative term (median speech count of 101), German MPs delivered 18 speeches on average (median of 15) during the 2005-09 legislative term. ${ }^{21}$ On average, German MPs deliver fewer speeches than their British counterparts. This reflects the UK House of Commons' long history as a forum for adversarial political debate. We first run models with all MPs and without the distance variables. These constitute our baseline models. ${ }^{22}$

For the United Kingdom, the party leader variable is positive and significant (Model 1). This effect is primarily driven by the governing Labour party members, as was suggested by the aggregate analysis (see Figure 2a). Once we exclude Labour MPs from the analysis and keep only the opposition Conservative MPs (Model 2), the party leader effect disappears. When we include the distance variable, we are able to keep around a third of MPs in the sample. The results confirm our expectation: we find that ideological distance from one's party leadership actually has a slightly positive and significant impact on the likelihood that an MP speaks. Members at odds with their party leadership are not kept off the floor, but rather speak more frequently than members closer to their parties' leadership (Model 3). This result is robust to the inclusion of a party dummy.

In Germany, our baseline model with all MPs predicts that leaders speak more often, that party-list MPs are more active, and that more committee assignments, i.e.,

\footnotetext{
${ }^{20}$ Likelihood ratio tests for overdispersion are statistically significant.

${ }^{21}$ This difference is slightly deceiving because we were able to remove speeches from the German dataset given by MPs in their function as government members, whereas we were not able to do the same for the United Kingdom due to the way speeches are recorded in the parliamentary archives.
}

${ }^{22}$ We only include MPs serving the full term. higher policy expertise, also lead to more speech counts on the floor (Model 1). These results confirm the aggregate analysis. When we consider ideological distance from the party leadership, we do indeed find a negative effect, as the theoretical model predicts (Model 2). This is in stark contrast to the positive effect of distance on speech counts in the United Kingdom. As a German MP's ideological distance increases from the party leader position on the left-right scale, the MP gives fewer speeches. This effect holds when we control for the status of the MP. The findings again confirm the party-level analysis. List MPs tend to give more speeches, as do party leaders. The effects for list/district status and leaders, while always positive, do not remain statistically significant once we include party dummies (Models 3-5). This is not surprising as only the large parties SPD and CDU/CSU are successful in winning single-member districts. Therefore, party dummies correlate highly with MP status. Lastly, we have included a dummy variable to control for whether MPs from the governing parties (SPD and CDU/CSU) were located inside the interval of the governing coalition (Models 4 and 5). This variable allows us to test whether MPs may be expected to follow the coalition, rather than a party line. However, we find little evidence for this. The ideological distance variable remains statistically significant, and the coalition dummy is not. This effect holds both when we consider all MPs (Model 4) and only MPs from the governing coalition (Model 5). Thus, given the ideological distance for each MP, coalition effects do not explain any additional variation in speech counts.

In order to understand the substantive magnitude of the effects found in the above models, as well as the associated uncertainty, we simulate expected speech counts and corresponding 95\% confidence intervals for the ideological distance variable on the basis of Model 3 (United Kingdom) and Model 4 (Germany). The quantities of interest are shown in Figure 3. The German model predicts that backbenchers whose left-right position is identical to the party position give around 16 speeches, whereas MPs who maximally disagree with the party leadership deliver only 10 speeches, almost $40 \%$ fewer speeches. The UK model, in contrast, predicts that backbenchers who are ideologically close to the leadership give around 109 speeches, and MPs who disagree the most around 202 speeches, thus almost doubling the number of speeches. The magnitude of the effects of ideological distance is thus quite substantial. ${ }^{23}$

\footnotetext{
${ }^{23}$ In addition, for Germany, we simulated predicted speech counts and $95 \%$ confidence intervals for different types of MPs (list vs. district). Due to space constraints, we report them in a table in the supplementary appendix.
} 
TABLE 1 Negative Binomial Models of Legislative Speech Counts in Germany (2005-2009) and the UK (2001-2005)

\section{(A): UK House of Commons, 2001-2005}

\begin{tabular}{lccc}
\hline & Model 1 & Model 2 & Model 3 \\
Distance MP to Party Leadership & & & $0.118^{*}$ \\
& & $0.064)$ \\
Party Leader & $0.334^{*}$ & 0.078 & 0.434 \\
& $(0.150)$ & $(0.225)$ & $(0.335)$ \\
Party: Conservatives & $0.295^{* * *}$ & & $0.379^{* *}$ \\
& $(0.092)$ & & $(0.160)$ \\
Constant & $4.785^{* * *}$ & $5.100^{* * *}$ & $4.643^{* * *}$ \\
Theta & $(0.052)$ & $(0.066)$ & $(0.171)$ \\
& $1.105^{* * *}$ & $1.676^{* * *}$ & $1.351^{* * *}$ \\
Log-likelihood & $(0.064)$ & $(0.185)$ & $(0.146)$ \\
$\mathrm{N}$ & -3056.732 & -918.968 & -918.180 \\
\hline
\end{tabular}

(B): German Bundestag, 2005-2009

\begin{tabular}{|c|c|c|c|c|c|}
\hline & Model 1 & Model 2 & Model 3 & Model 4 & Model 5 \\
\hline \multirow[t]{2}{*}{ Distance MP to Party Leadership } & & $-0.588^{*}$ & -0.465 & $-0.571^{*}$ & $-0.829^{* *}$ \\
\hline & & $(0.327)$ & $(0.303)$ & $(0.316)$ & $(0.408)$ \\
\hline \multirow[t]{2}{*}{ Party Leader } & $0.562^{* * *}$ & $0.493^{* * *}$ & 0.242 & 0.253 & 0.173 \\
\hline & $(0.101)$ & $(0.184)$ & $(0.174)$ & $(0.174)$ & $(0.320)$ \\
\hline \multirow[t]{2}{*}{ Party List MP } & $0.493^{* * *}$ & $0.615^{* * *}$ & 0.103 & 0.102 & 0.149 \\
\hline & $(0.064)$ & $(0.110)$ & $(0.124)$ & $(0.123)$ & $(0.138)$ \\
\hline \multirow[t]{2}{*}{ MP Position Outside Coalition Interval } & & & & 0.147 & 0.190 \\
\hline & & & & $(0.133)$ & $(0.149)$ \\
\hline \multirow[t]{2}{*}{ Committee Assignments } & $0.108^{* * *}$ & $0.144^{* * *}$ & $0.126^{* * *}$ & $0.129^{* * *}$ & $0.181^{* * *}$ \\
\hline & $(0.020)$ & $(0.036)$ & $(0.033)$ & $(0.033)$ & $(0.044)$ \\
\hline \multirow[t]{2}{*}{ Party: CDU/CSU } & & & $-0.973^{* * *}$ & $-1.022^{* * *}$ & \\
\hline & & & $(0.193)$ & $(0.197)$ & \\
\hline \multirow[t]{2}{*}{ Party: SPD } & & & $-0.892^{* * *}$ & $-0.979^{* * *}$ & 0.035 \\
\hline & & & $(0.186)$ & $(0.200)$ & $(0.140)$ \\
\hline \multirow[t]{2}{*}{ Party: DIE LINKE } & & & -0.270 & -0.279 & \\
\hline & & & $(0.219)$ & $(0.218)$ & \\
\hline \multirow[t]{2}{*}{ Party: FDP } & & & -0.094 & -0.102 & \\
\hline & & & $(0.195)$ & $(0.194)$ & \\
\hline \multirow[t]{2}{*}{ Constant } & $2.201^{* * *}$ & $2.107^{* * *}$ & $3.074^{* * *}$ & $3.086^{* * *}$ & $1.917^{* * *}$ \\
\hline & $(0.080)$ & $(0.157)$ & $(0.238)$ & $(0.238)$ & $(0.195)$ \\
\hline \multirow[t]{2}{*}{ Theta } & $1.783^{* * *}$ & $1.979^{* * *}$ & $2.467^{* * *}$ & $2.483^{* * *}$ & $1.996^{* * *}$ \\
\hline & $(0.112)$ & $(0.222)$ & $(0.294)$ & $(0.297)$ & $(0.289)$ \\
\hline Log-likelihood & -2304.203 & -749.818 & -731.580 & -730.979 & -454.915 \\
\hline $\mathrm{N}$ & 604 & 197 & 197 & 197 & 132 \\
\hline
\end{tabular}

Note: The negative binomial models were estimated using the Zelig package (Imai, King, and Lau 2007). Table for UK: Baseline party is the Labour party; other parties are excluded in the models. Model 1 includes all MPs, Model 2 all Conservative MPs, and Model 3 all MPs who responded in the candidate survey. Table for Germany: Baseline party is the Green party. Models 1 and 2 include all MPs, Models 3 and 4 include all MPs who responded in the candidate survey and for whom a left-right position could be estimated, and Model 5 includes only government coalition MPs from the SPD and the CDU/CSU who responded to the candidate surveys. $\mathrm{P}$-values: $\mathrm{p} \leq 0.01={ }^{* * *}, \mathrm{p} \leq$ $0.05=^{* *}, \mathrm{p} \leq 0.1=^{*}$. 


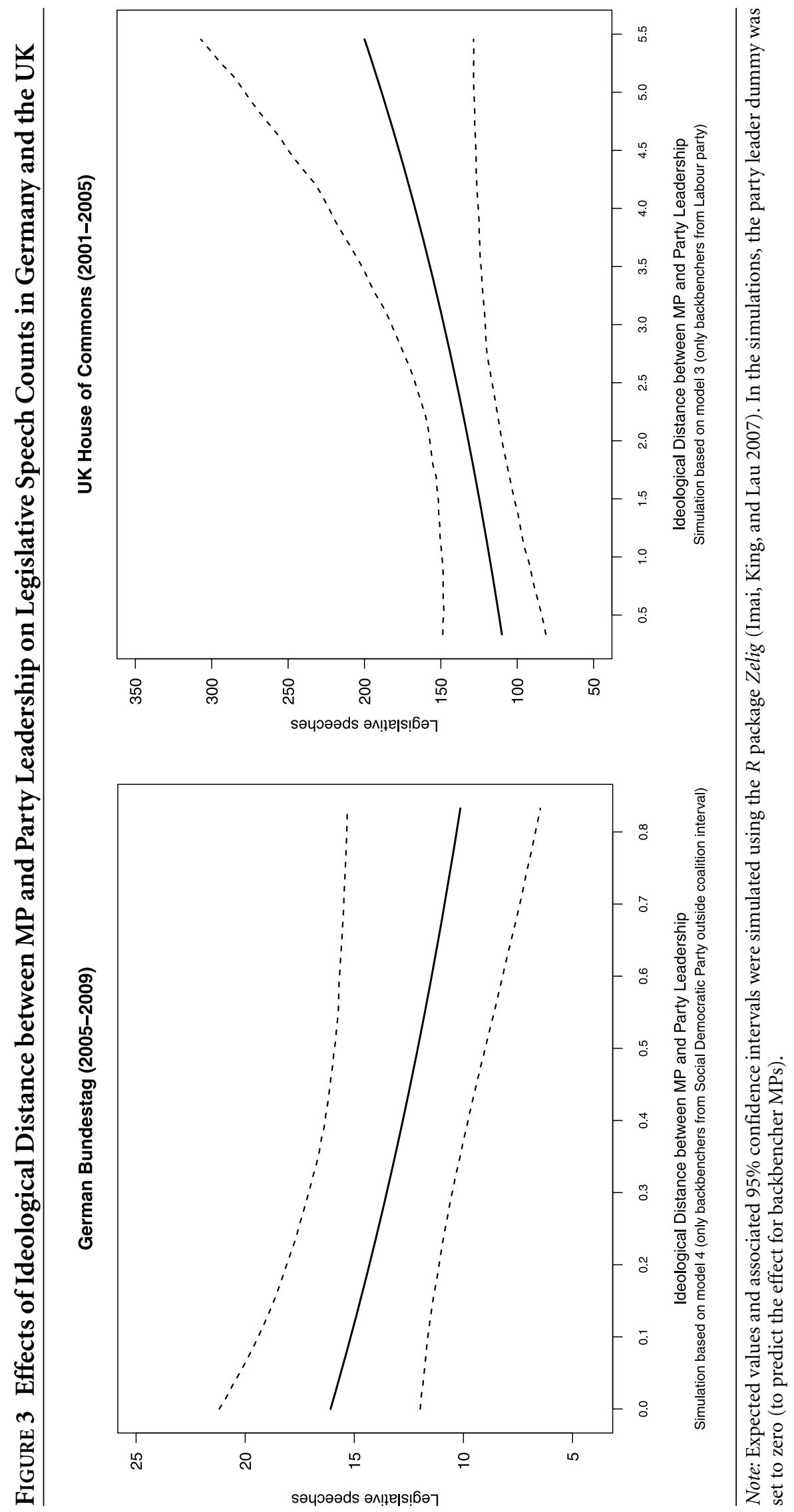


The above analyses do not differentiate between types of speech - a speech on the budget is counted the same as a speech on a private member's bill. Of course, party leaders may exert more pressure over their members in highly salient debates than they would when discussing a bill that has little chance at becoming law. To test whether results hold for the most salient debates, we examine the likelihood that members of the House of Commons and the Bundestag gave a speech during budget debates (2011 in the United Kingdom, and 2010 in the Bundestag). We run a probit model for each country, with participation in the budget debate as the dependent variable and party leadership, budget committee membership, and party dummies as the independent variables. We find that party leaders are significantly more likely than backbenchers to participate in the budget debate in Germany, but significantly less likely to participate in the United Kingdom. In Germany, being a party leader increases one's chance of speaking from approximately $17 \%$ to $51 \%$, while in the United Kingdom being a party leader decreases the likelihood of speaking from $28 \%$ to $19 \% .{ }^{24}$ Thus, our results hold for one of the most important debates of the parliamentary year.

\section{Conclusion}

This article has put forward a comparative institutional theory of legislative speech that embeds the organization of parliamentary debates into a strategic model of intraparty politics. When party leaders have a strong incentive to protect the party label, legislative speeches are unlikely to reflect true party cohesion as party leaders prevent potentially dissident backbenchers from taking the floor. We have tested central implications of our model using legislative speech data from the United Kingdom and Germany. German party leaders are relatively more active on the floor than backbenchers. The same, though, is not true in the United Kingdom, where the majoritarian electoral system provides leaders with fewer reasons to keep backbenchers off the floor.

More generally, we have introduced a model that informs us about how the party leadership controls the party message and organizes essential parliamentary activity. In doing so, we add to a growing literature exploring how party leaders use speech to send messages to, and coordinate activities among, party members, activists, and the electorate (see Dewan and Myatt 2008, forthcoming). Our main finding that, in many political systems, latent party cohesion is inversely related to party positions communi-

\footnotetext{
${ }^{24}$ Further details regarding this analysis are provided in the supplementary appendix.
}

cated in legislative speeches has consequences for anyone using legislative speeches to understand intraparty politics. Speeches may, in fact, underestimate the ideological differences within parties in many parliamentary systems. In addition, our findings regarding the German mixedmember system have consequences for political representation. One impetus for the creation of mixed-member PR systems is to increase opportunities for constituency representation. However, because of the importance of maximizing the list vote, parties may restrain district MPs from publicly representing constituency views when they conflict with the party leadership's position.

Lastly, our findings open up new avenues for study. Our model can be applied to similar problems pertaining to the communication of party policy. Applications include any situation in which time is scarce, leaders have an incentive to present the outside world a unified message, and institutions exist (or can be created) that allow them to do so. For example, should party leaders go on political talk shows themselves or delegate this task to a lower-ranking party member? And does the party have rules about MPs making such media appearances? Future research may also look closely at the actual concessions MPs make in speeches and the consequences of dissident legislative speech on MP's legislative careers. In addition, more work can be done to test our theory in political systems beyond the United Kingdom and Germany. Of particular interest may be countries where electoral laws have changed. Do rules regarding the allocation of speaking time change following electoral law changes? These questions are beyond the scope of this study, but they point to the variety of implications of our model.

\section{References}

Aldrich, John H. 1995. Why Parties? The Origin and Transformation of Political Parties in America. Chicago: University of Chicago Press.

Aldrich, John H., and Richard D. McKelvey. 1977. “A Method of Scaling with Applications to the 1968 and 1972 Presidential Elections.” American Political Science Review 71(1): 111-30.

Austen-Smith, David. 1990. "Information Transmission in Debate." American Journal of Political Science 34(1): 124-52.

Bawn, Kathleen, and Gregory Koger. 2008. "Effort, Intensity and Position Taking: Reconsidering Obstruction in the PreCloture Senate." Journal of Theoretical Politics 20(1): 67-92.

Bowler, Shaun. 2000. "Parties in Legislatures: Two Competing Explanations." In Parties without Partisans: Political Change in Advanced Industrial Democracies, ed. R. J. Dalton and M. P. Wattenberg. Oxford: Oxford University Press, 157-79.

Bundestag. 1998. "Die Mitglieder des Deutschen Bundestages 1.-13. Wahlperiode." Materialien des Wissenschaftlichen Dienstes des Deutschen Bundestages 127. 
Butler, David, and Gareth Butler. 2005. British Political Facts since 1979. London: Palgrave Macmillan.

Carey, John M. 2007. "Competing Principals: Political Institutions and Party Unity in Legislative Voting." American Journal of Political Science 51(1): 92-107.

Carey, John M. 2009. Legislative Voting and Accountability. Cambridge: Cambridge University Press.

Carey, John, and Matthew Shugart. 1995. "Incentives to Cultivate a Personal Vote: A Rank Ordering of Electoral Formulas.” Electoral Studies 14(4): 417-39.

Carrubba, Clifford J., Matthew J. Gabel, and Simon Hug. 2008. "Legislative Voting Behavior, Seen and Unseen: A Theory of Roll-Call Vote Selection." Legislative Studies Quarterly 23(4): 543-72.

Carrubba, Clifford J., Matthew J. Gabel, Lacey Murrah, Ryan Clough, Elizabeth Montgomery, and Rebecca Schambach. 2006. "Off the Record: Unrecorded Legislative Votes, Selection Bias and Roll-Call Vote Analysis." British Journal of Political Science 36(4): 691-704.

Cox, Gary. 2006. "The Organization of Democratic Legislatures." In The Oxford Handbook of Political Economy, ed. Barry Weingast and Donald Wittman. Oxford: Oxford University Press, 141-61.

Cox, Gary, and Matthew McCubbins. 1993. The Legislative Leviathan. Berkeley: University of California Press.

Cox, Gary W., and Matthew D. McCubbins. 2005. Setting the Agenda: Responsible Party Government in the US House of Representatives. Cambridge: Cambridge University Press.

Crisp, Brian, Maria Escobar-Lemmon, Bradford Jones, Mark Jones, and Michelle Taylor-Robinson. 2004. "Vote-Seeking Incentives and Legislative Representation in Six Presidential Democracies." Journal of Politics 66(3): 823-46.

Dewan, Torun, and David P. Myatt. 2008. "The Qualities of Leadership: Direction, Communication, and Obfuscation." American Political Science Review 102(3): 351-68.

Dewan, Torun, and David P. Myatt. Forthcoming. "The Rhetorical Strategies of Leaders: Speaking Clearly, Standing Back, and Stepping Down." Journal of Theoretical Politics.

Diermeier, Daniel, and Timothy Feddersen. 1998. "Cohesion in Legislatures and the Vote of Confidence Procedure." American Political Science Review 92(3): 611-21.

Diermeier, Daniel, Jean-Francois Godbout, Bei Yu, and Stefan Kaufmann. 2012. "Language and Ideology in Congress." British Journal of Political Science 42(1): 31-55.

Döring, Herbert. 1995. "Time as a Scarce Resource: Government Control of the Agenda." In Parliaments and Majority Rule in Western Europe, ed. Herbert Döring. Frankfurt: Campus Verlag, 223-46.

Gallagher, Michael, and Michael Marsh, eds. 1988. Candidate Selection in Comparative Perspective: The Secret Garden of Politics. London: Sage.

Gay, Oonagh. 2009. "Members since 1979." House of Commons Library Research Paper 09/31. Available at http://www.parliament.uk.

Giannetti, Daniela, and Michael Laver. 2005. "Policy Positions and Jobs in the Government." European Journal of Political Research 44(1): 91-120.

Gschwend, Thomas, Hermann Schmitt, Andreas Wüst, and Thomas Zittel. 2005. German Candidate Survey, Bundestag
Election 2005 (ZA4923 data set). Mannheim Center for European Social Research (MZES) and GESIS Cologne.

Harris, Douglas B. 2005. "Orchestrating Party Talk: A PartyBased View of One-Minute Speeches.” Legislative Studies Quarterly 30(1): 127-41.

Hix, Simon. 2004. "Electoral Institutions and Legislative Behavior: Explaining Voting Defection in the European Parliament." World Politics 56(1): 194-223.

Hix, Simon, Abdul Noury, and Gerard Roland. 2007. Democratic Politics in the European Parliament. Cambridge: Cambridge University Press.

Huber, John D. 1996. "The Vote of Confidence in Parliamentary Democracies." American Political Science Review 90(2): 269-82.

Hug, Simon. 2010. "Selection Effects in Roll Call Votes." British Journal of Political Science 40(1): 225-35.

Imai, Kosuke, Gary King, and Olivia Lau. 2007. "negbin: Negative Binomial Regression for Event Count Dependent Variables." Zelig: Everyone's Statistical Software. http://gking.harvard.edu/zelig.

Kam, Christopher J. 2009. Party Discipline and Parliamentary Politics. Cambridge: Cambridge University Press.

Laver, Michael, and Kenneth Benoit. 2002. "Locating TDs in Policy Spaces: Wordscoring Dail Speeches." Irish Political Studies 17(1): 59-73.

Londregan, John. 2002. "Appointment, Reelection, and Autonomy in the Senate of Chile." In Legislative Politics in Latin America, ed. Scott Morgenstern and Benito Nacif Cambridge: Cambridge University Press, 34176.

Maltzman, Forrest, and Lee Sigelman. 1996. "The Politics of Talk: Unconstrained Floor Time in the US House of Representatives." Journal of Politics 58(3): 819-30.

Martin, Lanny W., and Georg Vanberg. 2008. "Coalition Government and Political Communication." Political Research Quarterly 61(3): 502-16.

McKay, William, ed. 2004. Erskine May's Treatise on the Law, Privileges, Proceedings and Usage of Parliament. 23rd ed. London: Lexis Nexis Butterworths.

Monroe, Burt L., Michael Colaresi, and Kevin M. Quinn. 2008. "Fightin' Words: Lexical Feature Selection and Evaluation for Identifying the Content of Political Conflict." Political Analysis 16(4): 371-403.

Monroe, Burt L., and Ko Maeda. 2004. “Talk's Cheap: TextBased Estimation of Rhetorical Ideal-Points." Presented at the 21st Meeting, Society for Political Methodology, Stanford University.

Morris, Jonathan S. 2001. "Reexamining the Politics of Talk: Partisan Rhetoric in the 104th House." Legislative Studies Quarterly 26(1): 101-21.

Norris, Pippa, and Joni Lovenduski. 2001. "The British Representation Study, 2001." Available at http// www.hks.harvard.edu/fs/pnorris/datafiles/BRS2001.zip.

Poole, Keith, Howard Rosenthal, Jeffrey Lewis, James Lo, and Royce Carroll. 2010. "basicspace: A Package to Recover a Basic Space from Issue Scales.” Version 0.01.

Proksch, Sven-Oliver, and Jonathan B. Slapin. 2010. "Position Taking in European Parliament Speeches." British Journal of Political Science 40(3): 587-611. 
Quinn, Kevin M., Burt L. Monroe, Michael Colaresi, Michael H. Crespin, and Dragomir Radev. 2010. "How to Analyze Political Attention with Minimal Assumptions and Costs." American Journal of Political Science 54(1): 209-28.

Roberts, Jason M. 2007. “The Statistical Analysis of Roll-Call Data: A Cautionary Tale." Legislative Studies Quarterly 32(3): 341-60.

Schonhardt-Bailey, Cheryl. 2005. "Measuring Ideas More Effectively: An Analysis of Bush and Kerry's National Security Speeches.” PS Political Science and Politics 38(4): 701-11.

Schonhardt-Bailey, Cheryl. 2008. "The Constitutional Debate on Partial-Birth Abortion: Constitutional Gravitas and Moral Passion.” British Journal of Political Science 38(3): 383-410.

Schreiner, Hermann J. 2005. “Die Berliner Stunde-Funktionsweise und Erfahrungen: Zur Redeordnung des Deutschen Bundestages." Zeitschrift für Parlamentsfragen 36(3): 573-88.

Shepsle, Kenneth A., and Barry R. Weingast. 1987. "The Institutional Foundations of Committee Power." American Political Science Review 81(1): 85-104.

Thomas, Matt, Bo Pang, and Lillian Lee. 2006. "Get Out the Vote: Determining Support or Opposition from Congressional Floor-Debate Transcripts." In Proceedings of Empirical Methods in Natural Language Processing Conference, 2006 Conference on Empirical Methods in Natural Language Processing, Sydney, Australia, 327-35.

Tsebelis, George. 2002. Veto Players: How Political Institutions Work. Princeton, NJ: Russell Sage/Princeton University Press.

Wüst, Andreas M., Hermann Schmitt, Thomas Gschwend, and Thomas Zittel. 2006. "Candidates in the 2005 Bundestag
Election: Mode of Candidacy, Campaigning and Issues." German Politics 15(4): 420-38.

Zittel, Thomas, and Thomas Gschwend. 2008. "Individualized Campaigns in Mixed-Member Systems. Candidates in the German Federal Elections 2005." West European Politics 31(5): 978-1003.

\section{Supporting Information}

Additional Supporting Information may be found in the online version of this article:

Appendix A. Proof to Speech Delegation Game

Appendix B. Party Group Rules on Legislative Debate in Germany

Appendix C. Predicted Speech Counts in the German Bundestag for Different Types of MPs

Appendix D. Robustness Checks

Appendix E. Mentions of Parliamentary Debates in Germany in FAZ

Appendix F. Hours Spent on Parliamentary Debates in the UK

Please note: Wiley-Blackwell is not responsible for the content or functionality of any supporting materials supplied by the authors. Any queries (other than missing material) should be directed to the corresponding author for the article. 